\title{
GRAIN REFINEMENT THROUGH DESIGN MODIFICATION OF ECAP DIES
}

\section{PANKAJ KUMAR ${ }^{1} \&$ J. HARIVIGNESH ${ }^{2}$}

${ }^{I} P G$ Scholar, School of Mechanical Engineering, Advanced Manufacturing SASTRA University Thanjavur, India

${ }^{2}$ Assistant Professor, School of Mechanical Engineering, Sastra University Thanjavur, India

\begin{abstract}
The need for super-plasticity and high strength leads to the development of Severe Plastic Deformation (SPD) techniques. The strength of the material is directly dependent upon the grain size of the material. During the simulation of ECAP process, the initial die designed with sharp corner angle reveals metal flash. Metal flash may fail the tip of the billet. To avoid and control the metal flash, the intersecting channels are redesigned with radius of $3 \mathrm{~mm}$ and reveals smooth flow. ECAP die $90^{\circ}$ and $120^{\circ}$ for square billets are made in H11 Steel channels, that are cut into $58 \times 9.2 \times 8.2 \mathrm{~mm}$ for $90^{\circ}$ machined in EDM process, similarly $120^{\circ}$ die with $52 \times 9.2 \times 8.2 \mathrm{~mm}$ are made, including the Punch are made in same material of $155 \times 9.2 \times 8.2 \mathrm{~mm}$, respectively. Aluminum Automobile scrap were selected and melted in the open hearth furnace, made round rods and square billets as per the die dimensions. Molybdenum di- sulphate, is used as a lubricant. Tensile Test was carried out for the Annelid specimen. Brinell hardness was checked and SEM test was carried out, for finding out the reason for the failure.
\end{abstract}

KEYWORDS: Severe Plastic Deformation (SPD), ECAP, Ultrafine refinement(UFG), Microstructure \& Strain rate

Received: Nov 13, 2017; Accepted: Dec 04, 2017; Published: Dec 21, 2017; Paper Id.: IJMPERDFEB20185

\section{INTRODUCTION}

Equal channel Angular (ECAP) is a process of producing ultra-fine grain (UFG) structure in bulk material. It was developed by Segal and it is the most severe plastic deformation (SPD). The principal of material grain size is used to make effects on material properties. More research is going on in ECAP, based on pure metals and metallic alloys. The Severe Plastic Deformation (SPD) is a process for deformation method, to produce more amount of ultra-fine grain or sub-micron grain, with mechanical and physical properties. The technique is used in this shape of the work piece, which will not be modified and the microstructure of the deformed metal result in improvement in the form of both physical and mechanical properties, like Tensile/Compression Strength, Yield Stress, elongation and fatigue life.

\section{EXPERIMENTAL MATERIALS AND PROCEDURES}

\section{Material Selection and Characterization}

H11 is a special alloy steel, categorized as chromium tool steel, because of its high toughness and hardness; it is well suited for hot work applications, involving very high loads. Typical applications are hot-work forging and extrusion dies, helicopter rotor blades, etc.

\section{Image Analysis of H11 Die Steel}

Metallographic Test is used, to analyses the microstructure of the specimen. A part of the specimen was cut from the sample. The face of the material is polished using four grade of the emery sheet, to obtain fine 
polished outlook without scratch. The specimen is allowed to further polishing in grinding machine, with the addition of alumina. Then, Nital a mixture of $4 \%$ nitrogen and $96 \%$ of ethanol is applied partially, to the face of the specimen and dried for 5 minutes. Then, the specimen is placed under electron microscope, to obtain clear microstructure.

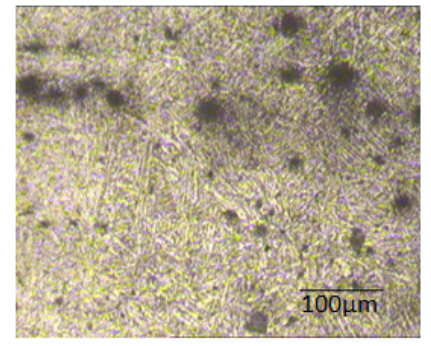

Figure 1: Micro Structure of H11 Die Steel

\section{Image Analysis of Scrap Melted Al Alloy}

Metallographic Test is used to analyze the microstructure of the specimen. A part of the specimen was cut from the sample. The specimen is of the aluminum alloy, made from automobile AL scrap. The face of the material is polished using four grade of the emery sheet, to obtain fine polished outlook without scratch. Then, Nital a mixture of $4 \%$ nitrogen and $96 \%$ of ethanol is applied partially to face of specimen and dried for 5 minutes. Then, the specimen is placed under electron microscope to obtain clear microstructure.

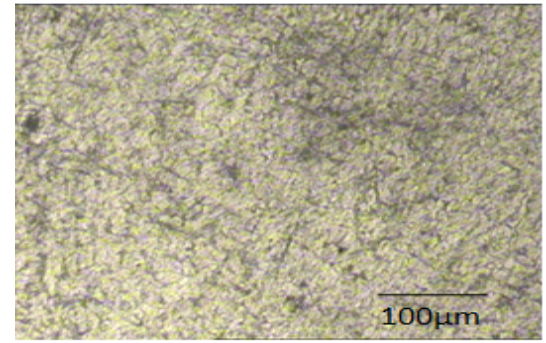

Figure 2: Micro Structure of Scrap Melted Aluminum Alloy

\section{Chemical Composition}

To analyze the composition of the material, chemical composition test was carried out using PAA (Portable Alloy Analyzers in SPF).

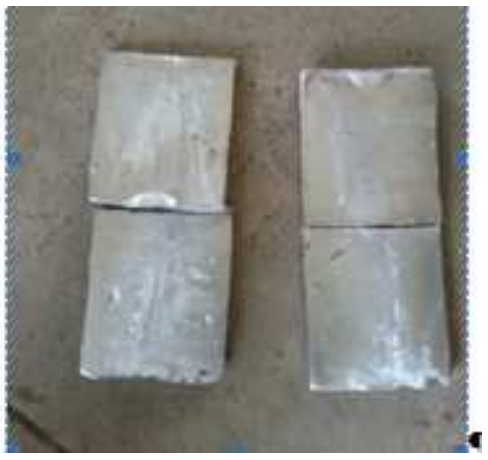

Figure 3: Square Plate 


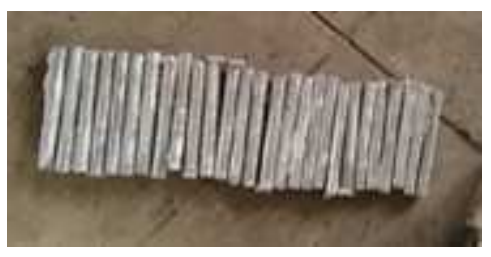

Figure 4: Scrap melted of Al Alloy Circular Rod

The result of the sample was tested as per the specification, for the Aluminum composite. Table one, shows the composition of the Automobile Aluminum Scrap.

Table 1

\begin{tabular}{|l|l|}
\hline $\mathrm{Si}$ & 9.77 \\
\hline $\mathrm{Al}$ & 81.18 \\
\hline $\mathrm{Mg}$ & 5.34 \\
\hline $\mathrm{Pb}$ & 0.09 \\
\hline $\mathrm{Zn}$ & 1.30 \\
\hline $\mathrm{Cu}$ & 0.91 \\
\hline $\mathrm{Ni}$ & 0.09 \\
\hline $\mathrm{Fe}$ & 0.99 \\
\hline $\mathrm{Mn}$ & 0.18 \\
\hline $\mathrm{Cr}$ & 0.16 \\
\hline
\end{tabular}

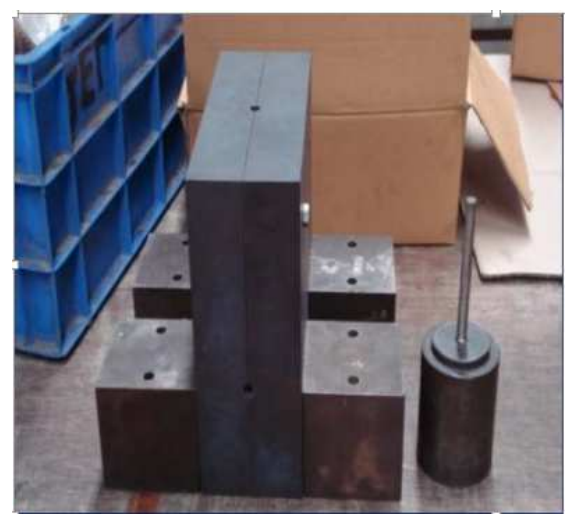

Figure 5: ECAP Die with Punch

\section{Hardness Test}

Brinell hardness testing machine is used to measure the hardness of the specimen.

For consideration of Automobile AL Scrap Diamond intender is chosen, as per standards and Hardness of the specimen is measured. The results obtained using Brinell hardness testing is shown in Table 1 .

Table 2

\begin{tabular}{|l|l|l|c|}
\hline $\begin{array}{c}\text { No of } \\
\text { Pieces }\end{array}$ & Temperature & \multicolumn{1}{|c|}{ Time } & BHN \\
\hline $1^{\text {st }}$ & $350 \mathrm{c}$ & $1 \mathrm{hr}$ & $48.3 \mathrm{HB}$ \\
\hline $2^{\text {nd }}$ & $350 \mathrm{c}$ & $2 \mathrm{hr}$ & $49.2 \mathrm{HB}$ \\
\hline $3^{\text {rd }}$ & $350 \mathrm{c}$ & $3 \mathrm{hr}$ & $49.3 \mathrm{HB}$ \\
\hline
\end{tabular}


Table 3

\begin{tabular}{|c|c|}
\hline $\mathrm{Si}$ & 22.48 \\
\hline $\mathrm{Al}$ & 73.12 \\
\hline $\mathrm{Sn}$ & 0.05 \\
\hline $\mathrm{Pb}$ & 0.27 \\
\hline $\mathrm{Zn}$ & 1.38 \\
\hline $\mathrm{Cu}$ & 1.28 \\
\hline $\mathrm{Ni}$ & 0.21 \\
\hline $\mathrm{Fe}$ & 0.97 \\
\hline $\mathrm{Mn}$ & 0.14 \\
\hline $\mathrm{Cr}$ & 0.11 \\
\hline
\end{tabular}

- UTM machine is used for pressing Force applied 70KN

- $\quad$ At 70KN Round Rod broken inside the ECAP Die

- $\quad$ Fracture Reveals like Brittle

- It was found that the circular rods and square plate to be heat treated for further fabrication

\section{Fractured Round Rod Specimen}

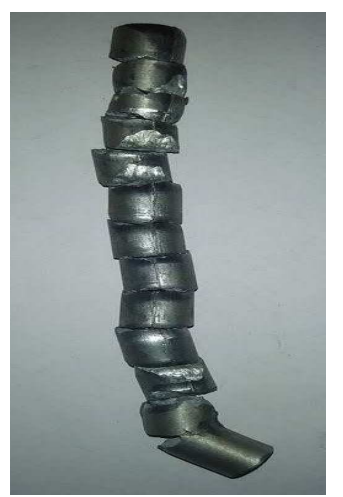

Figuer 6

Image shows fractured components of round rod, during ECAP process in $110^{\circ}$ die, under the load of $70 \mathrm{KN}$

- Tensile test was conducted on heat treated specimens, as per ASTM E8 standard

- $\quad$ Equipment used UTM machine model UTN 40

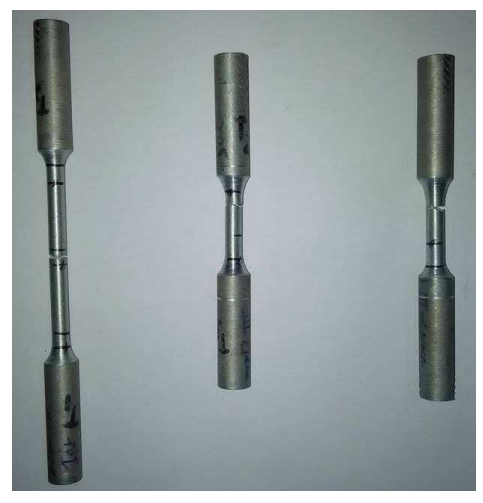

Figure 7 
- Image shows tensile specimen of heat treated samples machined as per ASTM E8 standard

- From Tensile Test report heat treated sample of $350^{\circ} \mathrm{C}$ at $3 \mathrm{hr}$ shows increased tensile strength $147.77 \mathrm{Mpa}$.

- Heat treated square plate samples are machined and prepared as per the Die requirements.

- In both die $90^{\circ}$ and $120^{\circ}$ channel surface, punch bottom surface, samples are well lubricated by Molybdenum Di sulphate.

- Samples are fabricated at room temperature in UTM machine with load applied constantly is 50KN.

- Samples are fractured in both the dies and punch is found slight bend at the top neck in $120^{\circ}$ die fabrication.

\section{FABRICATION OF ECAP DIES WITH PUNCH}

Equal Channel Angular Pressing (ECAP) means that its channel having the same crosses section throughout the channel. It is used for structural and landing gear application. Here ECAP of $90^{\circ} \& 120^{\circ}$ Die have been manufactured in SPF.

- H11 tool steel was selected

- For the specified Dimension H11 steel was machined

- First surfaces are grounded and made a holes and pins

- Flow channel prepared EDM machine with special copper electrode

\section{Fabrication of ECAP Die of $90^{\circ}$}

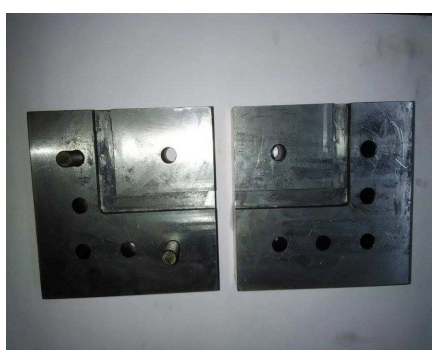

Figure 8: Ecap Die of $90^{0}$

\section{Fabrication of ECAP Die of $120^{\circ}$}

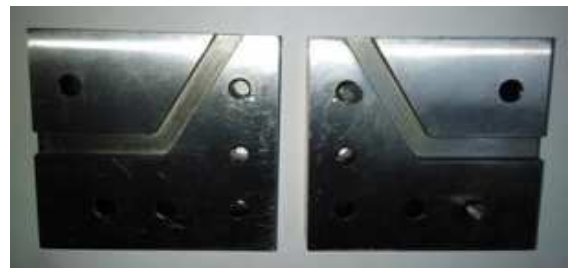

Figure 9: Ecap Die of $120^{0}$

\section{Fabrication of Punch}

Fabrication of Punch was done with the H11 Die Tool Steel. It is used for pressing the material inside the ECAP Die with uniform load. 


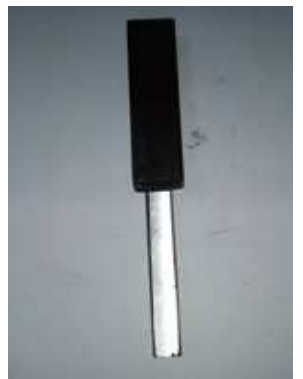

Figure.10: Punch of Ecap Dies

Specification of Punch

Total length: $155 \mathrm{~mm}$

Thickness: $8.2 \mathrm{~mm}$

Width: $9.2 \mathrm{~mm}$

\section{RESULT \& DISCUSSIONS}

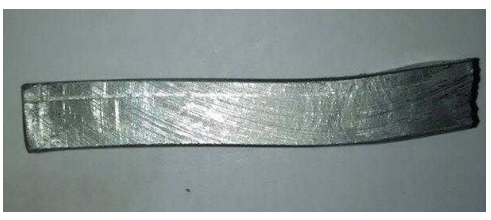

Figure.11: Image Shows Fractured Sample in $90^{\circ}$ Die

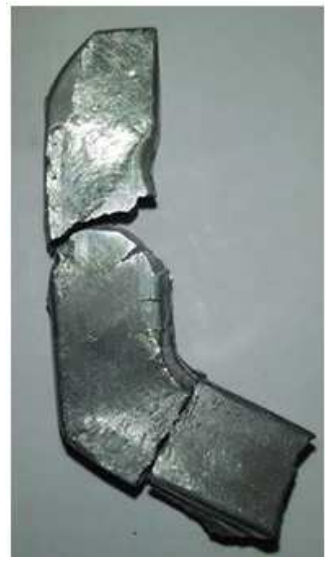

Figure 12: Image Shows Fractured Sample in $120^{\circ}$ die SEM Image (Failure Analysis Report)

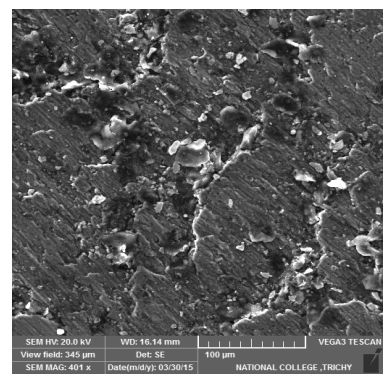

Figure 13: SEM Image of Fractured Specimen 
From the Tensile test, it is observed that round samples are failed like brittle fracture in $110^{\circ}$ die. Sample composition shows enrichment of silicon during the melting of $\mathrm{Al}$ - Si alloy to add Si stabilizer like sodium in melting. From phase 1 review simulation, the simulation results found in both die with curvature radius in corner maintained $3 \mathrm{~mm}$ results metal flow smoothly without any metal flash. Also, melting of aluminum in exposed atmosphere results formation of porosity and embrittlement. Heat treated square billets are fractured in both the dies and it shows ductile form of fracture due to the Si present in the sample and porosity in it. From SEM image Dimple region reveals ductile form of fracture.

\section{CONCLUSIONS}

- Design and simulation of ECAP Die result show metal can be fabricated without any metal flash.

- $\quad$ During the melting of Al-Si alloy should be performed in Vacuum furnace or inert gas equipped furnace.

- $\quad$ During charging of scrap, Si stabilizers like sodium should be added.

- Heating coil should be introduced in the die to fabricate the metals at high temperature or maintain annealed temperatures

- Also start practice fabricating with low melting and low dense materials like pure $\mathrm{Al}, \mathrm{Cu}$, and $\mathrm{Mg}$ alloys.

\section{REFERENCES}

1. N. Medeiros and L. P. Moreira - Upper-bound analysis of die corner gap formation for strain-hardening materials in ECAP process - Computational Materials Science 91 (2014) 350-358.

2. Oscar Fabián Higuera-Cobos a,b,n, Jonath Texture and fatigue behavior of ultra-fine-grained copper Produced by ECAP Materials Science \& Engineering A609(2014)273-282

3. Guanyu Deng, Cheng Lu - Influence of outer corner angle (OCA) on the plastic deformation and texture evolution in equal channel angular pressing - Computational Materials Science 81 (2014) 79-88.

4. Min Zha a, Yanjun Li - Dispersion of soft Bi particles and grain refinement of matrix in an Al-Bi alloy by equal channel angular pressing - Journal of Alloys and Compounds 605 (2014) 131-136.

5. Sagar Singh Parihar \& Rupesh Kumar Tiwari, Hybrid Slurry Abrasion Response of Die Casting Aluminium Alloy (LM-13) Under a Wide Range of Experimental Conditions, International Journal of Metallurgical \& Materials Science and Engineering (IJMMSE), Volume 5, Issue 3, May - June 2015, pp. 9-26

6. Muralidhar Avvari, S. Narendranath - Influence of Route-R on wrought magnesium AZ61 alloy mechanical properties through equal channel angular pressing - Journal of Magnesium and Alloys 2 (2014) 159 - 164.

7. Patil Basavaraj V. a,, Uday Chakkingalb, T. S. Prasanna Kumar - Effect of geometric parameters on strain, strain inhomogeneity and peak pressure in equal channel angular pressing - A study based on 3D finite element analysis - Journal of Manufacturing Processes (2014).

8. R. Haghayeghi, P. Kapranos - An investigation on work hardening of Al-1\%Mg processed by Equal Channel Angular Pressing - Materials Letters129(2014)182-184.

9. T. Mounika, K. V. P. Chakradhar \& V. Srinivas Viswanath, Die Designing and Molten Metal Flow Analysis for Parking Brake Piston, International Journal of Mechanical and Production Engineering Research and Development (IJMPERD), Volume 3, Issue 3, July - August 2013, pp. 99-108 
10. T. A. Lebedkina, M. A. Lebyodkin - Effect of equal channel angular pressing on the Portevin-Le Chatelier effect in an Al3Mg alloy - Materials Science \& Engineering A615 (2014) 7 - 13.

11. M. Rejaeian, M. Aghaie-Khafri - Study of ECAP based on stream function-Mechanics of Materials 76 (2014) $27-34$.

12. Ping LI, Ke-min XUE, Xiao-xi WANG, Chen-hao QIAN - Refinement and consolidation of pure Al particles by equal channel angular pressing and torsion - Trans. Nonferrous Met. Soc. China 24(2014) 1289-1294.

13. F. Djavanroodi, B. Omranpour, M. Ebrahimin, M. Sedighi - Designing of ECAP parameters based on strain distribution uniformity - Materials International 2012;22(5):452-460.

14. Ehab A. El-Danaf-Mechanical properties, microstructure and texture of single pass equal Channel angular pressed 1050, 5083, 6082 and 7010 aluminum alloys with different dies. Materials and Design 32 (2011) 3838-3853.

15. Kazeem O. Sanusil, Oluwole D. Makinde, Graeme J. Oliver2Equal channel angular pressing technique for the formation of ultra-fine grained structures. Sci 2012;108(9/10)sajs.co.za

16. M. H. Paydar, M. Reihanian, E. Bagherpour M. Sharifzadeh, M. Zarinejad, T. A. Dean . Equal channel angular pressingforward extrusion (ECAP-FE) consolidation of Al particles. Materials and Design 30 (2009) 429-432 